\title{
Biostimulation of inoculation with Glomus proliferum and application of humic acid in the in vitro growth of Lunularia cruciata ${ }^{1}$
}

\author{
Camila Pinheiro Nobre ${ }^{2,6}$, Orlando Carlos Tavares Huertas², José Rogério Figueira Tardin³, \\ Orivaldo José Saggin Júnior ${ }^{4}$, Henrique Manoel Apolónia Coutinho Fonseca ${ }^{5}$ and Ricardo Luis Louro Berbara ${ }^{2}$
}

Received: 17 October, 2012. Accepted: 1 August, 2013

\begin{abstract}
In this study, we evaluated the growth of the liverwort Lunularia cruciata, inoculated or not with the arbuscular mycorrhizal fungi (AMF) Glomus proliferum (15 spores per Petri dish), in Strullu-Romand Variant (SRV) medium modified and enriched with humic acid (HA) at different concentrations $\left(0,20,40\right.$ and $\left.80 \mathrm{mg} \mathrm{C} \mathrm{L}^{-1}\right)$, as well as the sporulation of the AMF. We assessed the absolute growth rate (AGR) and relative growth rate (RGR) at inoculation, as well as at 7, 14, 21, 28, 43, 52 and 60 days after inoculation (DAI), whereas we assessed sporulation at 25, 43, 60 and 70 DAI. The main determinant of L. cruciata growth was the presence of AMF. With and without G. proliferum inoculation, respectively, the AGR peaked at 39 and $42 \mathrm{DAI}$, and the RGR was 0.0474 and $0.0387 \mathrm{~cm}^{2} \mathrm{~cm}^{-2} \mathrm{~d}^{-1}$. Doses of 20 and $80 \mathrm{mg} \mathrm{C} \mathrm{L}^{-1}$ of HA had a positive influence on the growth of $L$. cruciata. With and without HA, respectively, the AGR peaked at 38 and 39 DAI, and the RGR was 0.0484 and $0.0422 \mathrm{~cm}^{2} \mathrm{~cm}^{-2} \mathrm{~d}^{-1}$. The sporulation of G. proliferum, which was as high as 199 spores plate ${ }^{-1}$, was influenced by HA, especially at 20 and $80 \mathrm{mg} \mathrm{C} \mathrm{L}^{-1}$.
\end{abstract}

Key words: arbuscular mycorrhizal fungi, liverworts, monoxenic cultures, humic substances

\section{Introduction}

Arbuscular mycorrhizal fungi (AMF) are organisms of the phylum Glomeromycota (Schüssler et al. 2001), considered one of the most important groups on the planet (Read 1992), because it is responsible for the mutualistic symbiotic relationship known as a mycorrhiza. Most plant families are able to form this type of relationship (Brundrett 2009; Wang \& Qiu 2006), including nonvascular plants such as liverworts (Fonseca et al. 2006; Ligrone et al. 2007; Fonseca et al. 2009). In the case of such plants, the relationships is referred to as arbuscular mycorrhiza-like (AML) symbiosis (Berbara et al. 2006; Moreira \& Siqueira 2006; Souza et al. 2010; Kottke \& Nebel 2005, Humphreys et al. 2010).

One of the main features of AMF is their obligate biotrophy, which means that they need a plant to complete their life cycle (Siqueira et al. 1985). Cultures are generally produced with a plant in soil (Fonseca et al. 2006) or through in vitro monoxenic culture with transformed roots (Bécard \& Fortin 1988; Souza \& Declerck, 2003). AMF culture techniques in axenic environments have been increasing with the optimization of in vitro studies (Declerck et al. 2005).
Alternatives have been sought for in vitro production of AMF, especially in relation to the plant symbiont. More recent work attempting to accomplish in vitro culture of AMF with stalks of Anthoceros punctatus L. reports the establishment of AML growth of external mycelium and the production of new glomerospores (Schüssler 2000). Since then, several studies with hornworts and liverworts collected from natural habitats have recorded the presence of mycorrhizal fungi in the stalk (Duckett et al. 2004; Russell \& Bulman 2005; Fonseca et al. 2006), indicating the possibility of using these plants as hosts for the in vitro culture of AMF. Fonseca et al. $(2006,2009)$ found that Glomus proliferum Dalpe \& Declerck managed to complete the life cycle and establish AML symbiosis when in the presence of Lunularia cruciata (L.) Dumortier ex. Lindberg in a Strullu-Romand Variant (SRV) culture medium modified from Strullu-Romand medium (Declerck et al. 1998; Fonseca et al. 2006) with $29.2 \mathrm{mM}$ sucrose, a 10/14-h light/dark cycle and a temperature of $25^{\circ} \mathrm{C}$. The attempt to use an avascular plant such as $L$. cruciata for in vitro culture creates the need to adapt the culture medium for the growth of AMF. Vitamins, amino acids and other growth-promoting substances should be tested to determine their efficiency in

\footnotetext{
${ }^{1}$ Based on the Master's dissertation of the first Author

${ }^{2}$ Universidade Federal Rural do Rio de Janeiro, Departamento de Solos, Instituto de Agronomia, Seropédica, RJ, Brazil

${ }^{3}$ Escola Nacional de Saúde Pública Sérgio Arouca, FIOCRUZ, Departamento de Endemias, Rio de Janeiro, RJ, Brazil

${ }^{4}$ Embrapa Agrobiologia - CNPAB, Seropédica,RJ, Brazil

${ }^{5}$ Universidade de Aveiro, Departamento de Biologia, Centro de Biologia Celular, Aveiro, Portugal

${ }^{6}$ Author for correspondence: camilaenobre@yahoo.com.br
} 
developing both the symbiont and the fungus in the in vitro culture. However, humic substances are macromolecules of high molecular weight, with no set formulation, typically composed of aromatic and aliphatic chains, as well as ketones, phenols, enols, etc. Humic substances are present in vermicompost and soil, and are subdivided into three fractions: humin, humic acid (HA) and fulvic acid (Santos \& Camargo 1999). The humic fractions influence soil fertility through the general improvement of physical and chemical conditions for biological activity and, moreover, because they contain physiologically active substances (Stevenson 1994; Façanha et al. 2002; Canellas et al. 2001, 2002; Nardi et al. 2007; Zandonadi et al. 2007). Thus, HA may influence rhizospheric biota, particularly AMF (Lima 2008). However, the effects of HA on mycorrhizae have been little studied. Gryndler et al. (2009) found that small amounts of organic soil matter can influence development and Gryndler et al. (2005) found that the addition of humic substance promoted the development of intra-and peri-apical AMF.

In the present study, we sought to determine the growth of Lunularia cruciata, inoculated or not with the AMF Glomus proliferum in a modified SRV medium enriched with HA. We also evaluated the sporulation of inoculated AMF.

\section{Materials and methods}

\section{Experiment setup}

Lunularia cruciata propagules were obtained from the growth of stalks in axenic cultures maintained in SRV medium at the Laboratory of Soil Biology at the Federal Rural University of Rio de Janeiro (Fonseca et al. 2006). The HA was extracted from cattle manure vermicompost. The extraction followed the methodology proposed by the International Humic Substances Society (Swift 1996) with adaptations (Benites et al. 2003). The HA had the following composition (Garcia et al. 2012a): $\mathrm{C}=56.7 \% ; \mathrm{H}=4.84 \%$; $\mathrm{O}=34.6 \% ; \mathrm{N}=3.07 \% ; \mathrm{S}=0.72 \% ; \mathrm{H} / \mathrm{C}=0.08 ; \mathrm{O} / \mathrm{C}=0.61$; $\mathrm{C} / \mathrm{N}=18.4$; carboxylic, phenolic and total acid $=9.2,2.03$, and $11.27 \mathrm{~mol} \mathrm{~kg}^{-1}(\mathrm{C})$, respectively; and $\mathrm{E}_{4} / \mathrm{E}_{6}$ ratio $=4.22$.

Liverwort segments of approximately $3.0 \mathrm{~cm}$ were transferred from the original Petri dishes to plates containing a medium enriched with varying levels of $\mathrm{HA}$ and cultured for one week at a temperature of $24^{\circ} \mathrm{C}$ and a 10/14-h light/ dark cycle. After this period, we performed the inoculation with the AMF, Glomus proliferum Dalpe \& Declerck (MUCL 41827) from the In vitro Glomeromycota Collection of the Mycology Department of the l'Université Catholique in Louvain, Belgium. The fungus multiplied and was maintained in monoxenic cultures of Lunularia cruciata. Fifteen glomerospores of G. proliferum were placed on each plate, as near as possible to the rhizoids.

The experiment consisted of the growth of the liverwort, inoculated or not with Glomus proliferum, in an SRV me$\operatorname{dium}\left(20 \mathrm{~g} \mathrm{~L}^{-1}\right.$ sucrose $)$ with varying doses of $\mathrm{HA}(20,40$ and
$80 \mathrm{mg} \mathrm{C} \mathrm{L}^{-1}$ ) and a control (without HA). The experimental design was completely randomized, with a $2 \times 4$ factorial arrangement in 6 repetitions (each plate constituted a repetition). The liverworts were transplanted, and, after one week, uncontaminated plates were either inoculated or not with the AMF. The growth of the liverwort was evaluated at inoculation, as well as at 7, 14,21, 28, 43, 52 and 60 days after inoculation (DAI). The number of glomerospores on the plates was evaluated at 25, 43, 60 and 70 DAI through direct counting of glomerospores with an inverted microscope.

\section{Statistical Analyses}

In relation to all variables studied, Lilliefors and Bartlett tests were performed for levels of $\mathrm{HA}$, the presence or absence of AMF and seasons after transplanting. The data were subjected to ANOVA ( $\mathrm{p}<0001)$, followed by regression analyses performed using the program SAEG 8.0 (UFV 2000).

Quantitative growth analysis - To monitor the growth of Lunularia cruciata, we used the technique proposed by Lima et al. (2006): photos of each experimental unit (plate) were taken and worked with in an image editor (Adobe Photoshop) and SIARCS software (Embrapa, Brasília, Brazil; http://www.catalogosnt.cnptia.embrapa.br/catalogo20/catalogo_de_produtos_e_servicos/arvore/CONTAG01_411_911200615045.html). The editing of images consisted only of cleaning, keeping the plant material in black and the rest of the image in white. The software used allowed us to determine the coverage area of the plate (in $\mathrm{cm}^{2}$ ) and the length (in $\mathrm{cm}$ ) of the organism under study.

We adopted the functional method for the coverage area of the plate and the data were fitted by regression, thus deriving the growth rates. Thus, among the various models proposed by Hunt (1981), we chose to work with the Richards model for area, based on iterative processes. Data analysis was guided by the ANOVA. The primary data showed strong heterogeneity among samples, and the functions were therefore fitted after the processing of the data by means of the natural logarithm in order to minimize the effect of heteroscedasticity (Neter \& Wasserman 1974; Araujo 2003). The model selection was based on the significance of the coefficients and the value of the coefficient of determination $\left(\mathrm{R}^{2}\right)$, in conjunction with the global trend of temporal variation of the variable measured. The Richards function, the absolute growth rate (AGR) and relative growth rate (RGR), respectively, were calculated according to the following expressions (Hunt 1981):

$$
\begin{aligned}
& C=a\left(1 \pm e^{(b-c T)}\right)^{-1 / d} \\
& A G R=\frac{a c e^{b-c T}}{d} \cdot\left(1 \pm e^{b-c T}\right)^{-(1 / d+1)} \quad\left(\mathrm{cm}^{2} \cdot \mathrm{day}^{-1}\right) \\
& R G R=\frac{c e^{b-c T}}{d\left(1 \pm e^{b-c T}\right)} \quad\left(\mathrm{cm}^{2}\right)
\end{aligned}
$$


where $T$ is time; $e$ is the exponent; and $a, b, c$, and $d$ are the coefficients of the Richards equation. The AGR expresses the rate of biomass production per unit of time. The RGR expresses the rate of biomass production per unit of preexisting material (Hunt 1981).

\section{Results and discussion}

As can be seen in Fig. 1, the ANOVA showed that, within the coverage area of the liverwort, there was a significant effect for the interaction $\mathrm{HA}^{\star} \mathrm{AMF}(\mathrm{p}<0.05)$. In the mycorrhizal liverworts, growth was unaffected by the lower doses of HA, showing an increase only at the highest dose. In the liverworts without AMF, the effect of the HA was apparent only at concentration of $80 \mathrm{mg} \mathrm{C} \mathrm{L}^{-1}$ of HA. Intermediate doses of HA (20 and $40 \mathrm{mg} \mathrm{C} \mathrm{L}^{-1}$ ) had an effect opposite of that expected, with the values of the area of liverwort being lower than those obtained with the control treatment. This may indicate a direct effect of the HA present in the medium, which could have altered the absorption of nutrients, probably in a dose-dependent manner.

Fonseca \& Berbara (2008) reported that in the presence of Glomus proliferum liverworts showed a mean reduction of $30 \%$ of dry weight as compared with non-inoculated specimens. The authors inferred that the fungus is a photosynthetic burden for the liverwort and characterized the association as parasitic and non-mutual, as expected. However, in the present study it was demonstrated that the association was mutual, since plant growth was favored by the colonization of the AMF, irrespective of the presence of humic substances.

The growth curve for the coverage area of the plates with the liverwort was sigmoidal. In the curve (Fig. 2a and $2 b$ ), we identified three phases, as described by Pereira and Machado (1987): in the initial phase (0-14 DAI), the area gradually increases or there occurs the establishment of

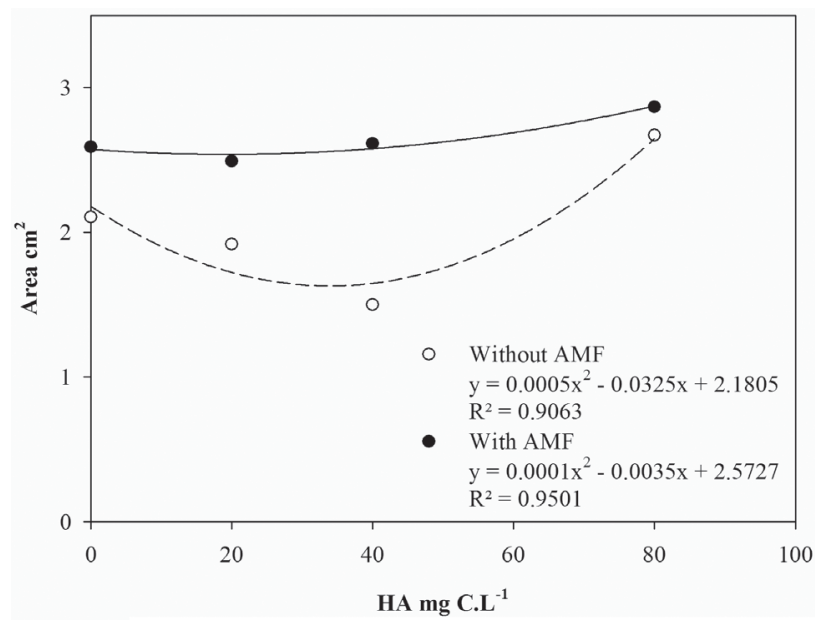

Figure 1. Area of the plate covered by the liverwort Lunularia cruciata, inoculated or not with the arbuscular mycorrhizal fungi (AMF) Glomus proliferum, by humic acid (HA) dose. the liverwort and symbiosis; the intermediate stage (15-42 DAI) corresponds to exponential or logarithmic growth-a continuous period of rapid plant growth and consolidation-resulting in liverworts twice their original size; and the final phase (from 43 DAI) was one of maturation, in which growth is once again slow or nonexistent.

Comparing the liverworts inoculated with Glomus proliferum and those not inoculated, the inoculated specimens showed a higher coverage area of the plate. The increase of the area over time indicates that from $7 \mathrm{DAI}$ to $60 \mathrm{DAI}$ the best results were found in plants inoculated with AMF (Fig. 2a), with the highest AGR occurring at 39 DAI with a value $0.107 \mathrm{~cm}^{2} \mathrm{~d}^{-1}$, whereas in the treatment with no AMF, the maximum AMF was observed at $42 \mathrm{DAI}$ with $0.084 \mathrm{~cm}^{2}$ $\mathrm{d}^{-1}$. Benincasa (2003) showed that the AGR can be used in order to estimate the average speed of growth over the period of evaluation. Because the AGR was reached sooner and with a greater value for the treatment with AMF than for the treatment without, these results indicate that the AML symbiosis promoted an increase in the speed of growth of the liverwort studied.

Treatment with $\mathrm{HA}$ at a concentration of $80 \mathrm{mg} \mathrm{C} \mathrm{L}^{-1}$ also promoted a greater increase in the liverwort area between 7 and 60 DAI compared with the HA-free medium (control) (Fig. 2b). The maximum AGR in the treatment with HA occurred at 38 DAI with $0.1076 \mathrm{~cm}^{2} \mathrm{~d}^{-1}$, and in the treatment without $\mathrm{HA}$ at 39 DAI with $0.0932 \mathrm{~cm}^{2} \mathrm{~d}^{-1}$. Therefore, $80 \mathrm{mg} \mathrm{C} \mathrm{L}^{-1}$ of HA also increased the speed of growth compared with the medium without HA (control).

The RGR is an important parameter in the evaluation of dry plant matter, being used in performance comparisons between different plants or to compare the effects of different treatments (Beadle 1987; Barcelos et al. 2007). The increases in RGR were $0.0474 \mathrm{~cm}^{2} \mathrm{~cm}^{-2} \mathrm{~d}^{-1}$ and $0.0387 \mathrm{~cm}^{2} \mathrm{~cm}^{-2} \mathrm{~d}^{-1}$ of growth, respectively, in liverworts with and without AMF. Thus, the RGR of the liverworts inoculated with the AMF showed higher values. However, over the course of the experiment, that rate began to decrease sharply (Fig. 2c). The RGR of the treatment without AMF remained almost constant until approximately $25 \mathrm{DAI}$, when it dropped, and the two curves intersected at $37 \mathrm{DAI}$ with an RGR of $0.032 \mathrm{~cm}^{2} \mathrm{~cm}^{-2} \mathrm{~d}^{-1}$. This behavior in the RGR demonstrates that inoculation favors the early development of the liverwort when compared with treatment without AMF. This shows the advantage provided by the AMF in terms of rapidity with which the plant establishes itself in a new environment, similar to what occurs in mycorrhizal plants transplanted to the field, which grow more vigorously and have an early start of production when compared with non-inoculated plants (Moreira \& Siqueira 2006).

The RGR of the liverworts treated with and without $\mathrm{HA}$ corresponded to $0.0484 \mathrm{~cm}^{2} \mathrm{~cm}^{-2} \mathrm{~d}^{-1}$ and $0.0422 \mathrm{~cm}^{2} \mathrm{~cm}^{-2}$ $\mathrm{d}^{-1}$, respectively. Therefore, the RGR of the liverworts treated with HA was higher. However, at approximately 28 DAI this rate decreased sharply, and the two curves intersected at $30 \mathrm{DAI}$ with $0.036 \mathrm{~cm}^{2} \mathrm{~cm}^{-2} \mathrm{~d}^{-1}$ (Fig. 2d). Therefore, it is 

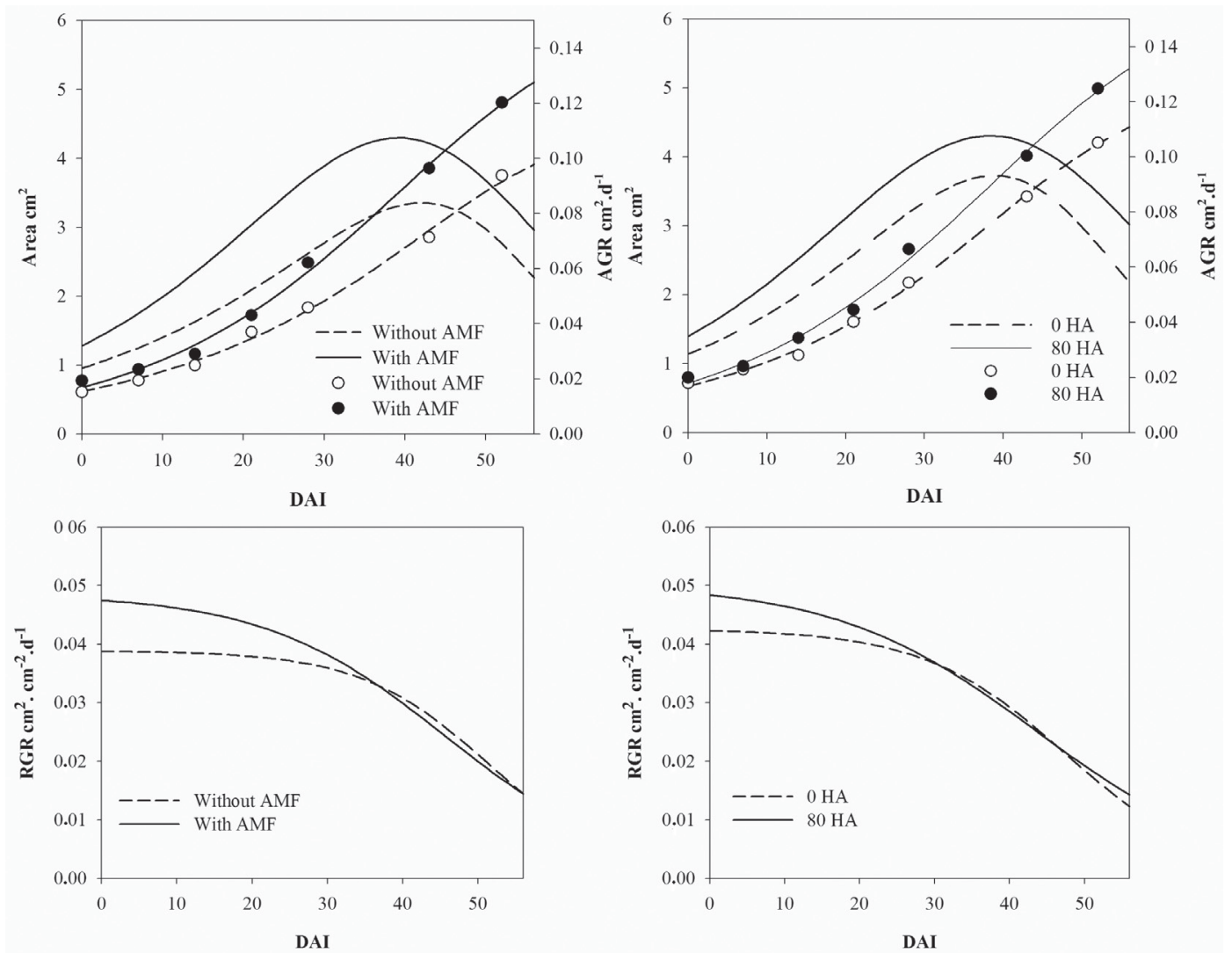

Figure 2. Results of cultures of the liverwort Lunularia cruciata*: (a) area of the plate covered by L. cruciata and absolute growth rate (AGR; • and $\circ$ for "with" and "without" conditions, respectively) with and without inoculation with the arbuscular mycorrhizal fungi (AMF) Glomus proliferum; (b) area of the plate covered by L. cruciata and AGR with 0 and $80 \mathrm{mg} \mathrm{C} \mathrm{L}^{-1}$ of humic acid (HA; $\bullet$ and o, respectively) in the SRV culture medium; (c) relative growth rate (RGR) with and without AMF inoculation; (d) RGR with 0 and 80 $\mathrm{mg} \mathrm{C} \mathrm{L}{ }^{-1}$ of HA in the SRV culture medium.

DAI - days after inoculation.

${ }^{*}$ Coefficients obtained via the Richards mathematical model and its coefficient of determination $\left(\mathrm{R}^{2}\right)$ of the treatments: with AMF$a=6.2817, b=3.7975, c=0.0831, d=1.7119$ and $\mathrm{R}^{2}=0.99$; without AMF $-a=4.5734, b=5.9914, c=0.1163, d=2.9935$ and $\mathrm{R}^{2}=0.99$; with HA $-a=6.624, b=3.2504, c=0.0745, d=1.4821$ and $\mathrm{R}^{2}=0.99$; and without HA $-a=5.086, b=5.0048, c=0.1055, d=2.478$ and $\mathrm{R}^{2}=0.99$.

clear that inoculation with AMF and the addition of HA, independently, stimulate the growth of liverworts. Considering that the life cycle of a liverwort in a Petri dish is limited to 100 days (unpublished data), it is likely that the rate of reduction in the RGR of Lunularia cruciata slowed over time. A reduction in RGR paralleling an advance in the physiological cycle has also been observed in other plants (Urchei et al. 2000; Zabot et al. 2004).

In evaluating the influence of the addition of different concentrations of HA to the culture medium, we observed that initial growth was similar at all doses, the effects of the addition of HA were evident only from 52 DAI and a dose of $80 \mathrm{C} \mathrm{mg} \mathrm{L}^{-1}$ promoted greater increases in growth of the liverwort (Fig. 3). The other doses (20 and $40 \mathrm{mg} \mathrm{C} \mathrm{L}^{-1}$ ) were not sufficient to increase plant growth when compared with the control treatment. The increase in liverwort area obtained with the highest dose of HA $\left(80 \mathrm{mg} \mathrm{C} \mathrm{L}^{-1}\right)$ is probably attributable to the increased availability of $\mathrm{C}$ in the culture medium.

Working with in vitro clover and basil roots and different concentrations of HA added to the culture medium,
Lima (2008) noted that the doses of 20 and $160 \mathrm{mg} \mathrm{C} \mathrm{L}^{-1}$ promoted root growth while 40 and $80 \mathrm{mg} \mathrm{C} \mathrm{L}^{-1}$ led to a reduction in growth rate. By monitoring the rhizosphere $\mathrm{pH}$, the author also found that decreases in the concentration of HA induced corresponding increases in acidification during root growth, acidification being greatest at a dose of $20 \mathrm{mg} \mathrm{C} \mathrm{L}{ }^{-1}$. Beginning at concentrations of $40 \mathrm{mg} \mathrm{C}$ $\mathrm{L}^{-1}$, acidification begins to decrease, and at a dose of 160 mg C L ${ }^{-1}$ the rhizosphere actually becomes alkali. Along with this phenomenon, we observed an adaptive response to the root growth medium with a high concentration of HA. In addition, alkalization of the $\mathrm{pH}$ in the rhizosphere may cause a reduction in the absorption of ions from the solution, resulting in impaired root development. Although similar behavior may have occurred in the liverwort plates, variations in $\mathrm{pH}$ were not analyzed during that experiment.

In addition to the growth of the liverwort, we assessed the sporulation of Glomus proliferum. The number of glomerospores recorded in the present study was lower than that observed by Fonseca et al. (2008). That difference might 


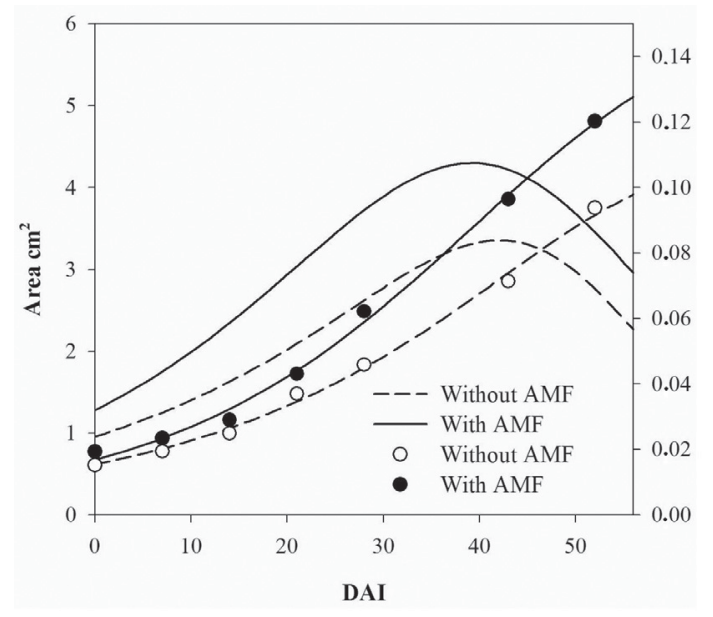

Figure 3. Average growth, in area, of the liverwort Lunularia cruciata cultured in SRV culture medium, with 0 and $80 \mathrm{mg} \mathrm{C} \mathrm{L}^{-1}$ of humic acid humic acid (HA), together with the absolute growth rate (AGR; $\bullet$ and $\circ$, respectively), at inoculation (0), as well as at 7, 14, 21, 28, 35, 42, 49 and 60 days after inoculation (DAI).

be attributable to the fact that those authors used a medium enriched with sucrose and P. In the present study, HA in SRV medium had a positive effect on the sporulation of G. proliferum at the lowest dose $\left(20 \mathrm{mg} \mathrm{C} \mathrm{L}^{-1}\right)$ and at the highest dose $\left(80 \mathrm{mg} \mathrm{C} \mathrm{L}^{-1}\right)$, the fungus reaching a production rate of 199 glomerospores plate ${ }^{-1}$ over the 70 -day experimental period (Fig. 4).

The effects of adding HA to plants are still poorly understood. Garcia et al. (2012b) studied the variation in HA exposure time and dose and found differences in the production of enzymes related to oxidative stress. Roots supplemented with humic substances present varying responses, including: positive influence on transportation and facilitation of the uptake of ions; increased respiration and rates of reactions that occur in the Krebs cycle, ensuring an increase in adenosine triphosphate (ATP) production; increased synthesis of nucleic acids and chlorophyll content and also an increase or inhibition of enzymes (Nannipieri et al. 1993; Façanha et al. 2002). In addition, biochemical mechanisms, such as ATPase activity, are stimulated by certain levels of HA (Varanini et al. 1993; Berbara et al. 1995; Façanha et al. 2002; Canellas et al. 2002).

The addition of HA to the culture medium can influence processes such as sporulation, production of external mycelium (Gryndler et al. 2005) and mycorrhizal colonization. Further studies are necessary to clarify this issue.

Liverworts inoculated with Glomus proliferum presented growth rates higher than those of non-inoculated liverworts, indicating the mutualistic nature of the relationship. Similarly, the enrichment of an SRV culture medium with HA at $80 \mathrm{mg} \mathrm{C} \mathrm{L} \mathrm{L}^{-1}$ promotes the development of Lunularia cruciata. Interaction between AMF inoculation and medium supplementation with $\mathrm{AH}$ can be observed in the area of plant cover, suggesting that this type of association may favor an increased photosynthetic rate, which is directly related to plant cover area. The production of glomerospores

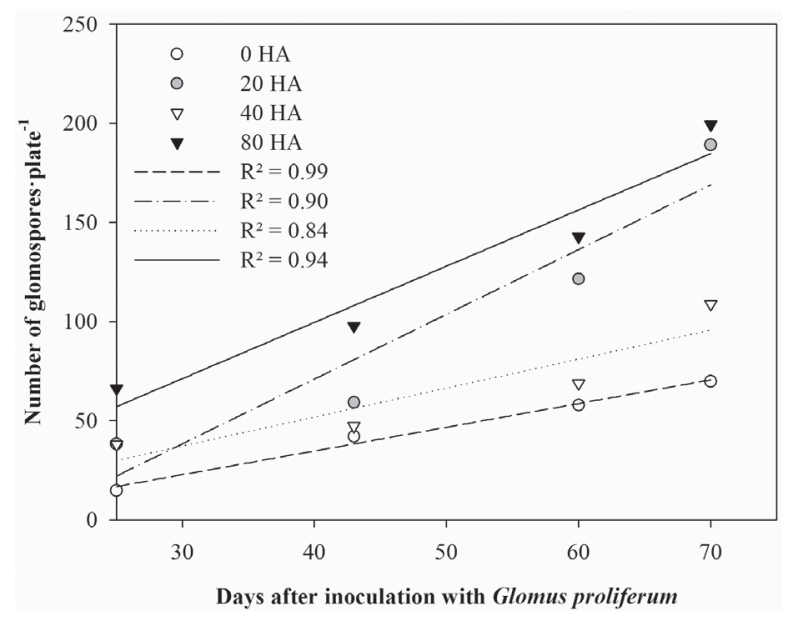

Figure 4. In vitro sporulation of Glomus proliferum associated with Lunularia cruciata in SRV culture medium with increasing doses of humic acid (HA; 0, 20, 40 and $80 \mathrm{mg} \mathrm{C} \mathrm{L}^{-1}$ ) at 25, 43, 60 and 70 days after inoculation (DAI).

was most pronounced at HA doses of 20 and $80 \mathrm{mg} \mathrm{C} \mathrm{L}^{-1}$, indicating that $\mathrm{HA}$ affects the process of multiplication of these glomerospores. Further studies are needed in order to elucidate the mechanisms responsible for this phenomenon.

\section{References}

Araújo, A.P. 2003. Analysis of variance of primary data on plant growth analysis. Pesquisa Agropecuária Brasileira 38(1): 1-10.

Barcelos, D.M.; Garcia, A.; Maciel Júnior, V.A. 2007. Análise de crescimento da cultura da batata submetida ao parcelamento da adubação nitrogenada em cobertura, em um latossolo vermelho-amarelo. Ciência e Agrotecnologia 31(1): 21-27.

Beadle, C.L. 1987. Plant-growth analysis. Pp. 20-25. In: Coombs, J. \& HALL, D.O. (Eds.). Techniques in bioproductivity and photosynthesis. Oxford. Pergamon.

Bécard, G. \& Fortin, J.A. 1988. Early events of vesicular-arbuscular mycorrhiza formation on Ri T-DNA transformed roots. New Phytologist 108: 211-218.

Benincasa, M.M.P. 2003. Análise de crescimento de plantas: noções básicas. 2 ed. Jaboticabal. Funep.

Benites, V.M.; Madari, B. \& Machado, P.L.O.A. 2003. Extração e fracionamento quantitativo de substâncias húmicas do solo: um procedimento simplificado de baixo custo. Comunicado Técnico 16, Rio de Janeiro, Embrapa Solos.

Berbara, R.L.L.; Morris, B.M.; Fonseca, H.M.A.C.; Reid, B.; Grow, N.A.R. \& Daft, M.J. 1995. Eletrical currents associated with arbuscular mycorrhizal interactions. New Phytologist 129: 433-438.

Berbara, R.L.L.; Souza, F.A. \& Fonseca, H.M.A.C. 2006. Fungos micorrízicos arbusculares: muito além da nutrição. Pp. 53-88. In: Fernandes, M.S. (Ed.). Nutrição Mineral de Plantas. Viçosa. SBCS. 1ed.

Brundrett, M.C. 2009. Mycorrhizal associations and other means of nutrition of vascular plants: understanding the global diversity of host plants by resolving conflicting information and developing reliable means of diagnosis. Plant Soil 320(1-2): 37-77.

Canellas, L.P.; Guridi, F.; Santos, G.A.; Rumjanek, V.M. \& Braz-Filho, R. 2001. Aumento da resolução de espectros de $\mathrm{RMN}{ }^{13} \mathrm{C}$ com uso de $\mathrm{KCl}$ 0,03 mol L ${ }^{-1}$. Química Nova 24: 131-132. Canellas, L.P.; Olivares, F.L.; Okorokova-Façanha, A.L. \& Façanha, A.R. 2002. Humic acids isolated from earthworm compost enhance root elongation, lateral root emergence, and plasma membrane $\mathrm{H}^{+}$-ATPase activity in maize roots. Plant Physiology 130: 1951-1957. 
Declerck, S.; Séguin, S. \& Dalpé, Y. 2005. The monoxenic culture of arbuscular mycorrhizal fungi as a tool for germoplasm collections. Pp. 17-30. In: Declerck, S.; Strullu, D.G. \& Fortin, J.A. (Eds.). In Vitro Culture of Mycorrhizas. Soil Biology, v 04. Berlin Heidelberg. Springer-Verlag.

Declerck, S.; Strullu, D.G. \& Plenchette, C.1998. Monoxenic culture of the intraradical forms of Glomus sp. isolated from a tropical ecosystem: a proposed methodology for germplasm collection. Mycologia 90: 579-585.

Duckett, J.G.; Burch, J.; Fletcher, P.W.; Matcham, H.W.; Read, D.J.; Russell, A. \& Pressel, S. 2004. In vitro cultivation of bryophytes: a review of practicalities, problems, progress and promise. Journal of Bryology 26: 3-20.

Façanha, A.R.; Façanha, A.; Olivares, F.L.; Guridi, F.; Santos, G.A.; Velloso, A.C.X.; Rumjanek, V.M.; Brasil, F.; Schrispema, J.; Braz-Filho, R.; Oliveira, M.A. \& Canellas, L.P. 2002. Bioatividade de ácidos húmicos: Efeitos sobre o desenvolvimento radicular e sobre a bomba de prótons da membrana plasmática. Pesquisa Agropecuária Brasileira 37: 1301-1310.

Fonseca, H.M.A.C.; Berbara, R.L.L. \& Pereira, M.L. 2006. Lunularia cruciata a potential in vitro host for Glomus proliferum and G. intraradices. Mycorrhiza 16: 503-508.

Fonseca, H.M.A.C \& Berbara, R.L.L. 2008. Does Lunularia cruciata form symbiotic relationships with either Glomus proliferum or G. intraradices? Mycological Research 112: 1063-1068.

Fonseca, H.M.A.C.; Ferreira, J.I.L; Berbara, R.L.L. \& Zatorre, N.P. 2009. Dominance of paris-type morphology on mycothallus of Lunularia cruciata colonized by Glomus proliferum. Brazilian Journal of Microbiology 40: 96-101.

García, A.C.; Berbara, R.L.L.; Portuondo, F.L; Izquierdo, F.G.; Gonzales Hernández, O.L. \& Castro, R.N. 2012a. Humic acids of vermicompost as an ecological pathway to increase resistance of rice seedlings to water stress. African Journal of Biotechnology 11: 3125-3134.

García, A.C.; Santos L.A.; Izquierdo, F.G.; Sperandio M.V.; Castro, N.R. \& Berbara, R.L.L. 2012b. Vermicompost humic acids as an ecological pathway to protect rice plant against oxidative stress. Ecological Engineering 47: 203-208.

Gryndler, M.; Hrselová, H.; Cajthaml, T.; Havránkov, M.; Rezácová, V.; Gryndlerrová, H. \& Larsen, J. 2009. Influence of soil organic matter decomposition on arbuscular mycorrhizal fungi in terms of asymbiotic hyphal growth and root colonization. Mycorrhiza 19: 255-266.

Gryndler, M.; Hrselová, H.; Sudová, R.; Gryndlerová, H.; Řezácová, V. \& Merhautová, V. 2005. Hyphal growth and mycorrhiza formation by the arbuscular mycorrhizal fungus Glomus claroideum BEG23 is stimulated by humic substances. Mycorrhiza 15: 483-488.

Humphreys, C.P.; Franks, P.J.; Rees, M.; Bidartondo, M.I.; Leake, J.R. \& Beerling, D.J. 2010. Mutualistic mycorrhiza-like symbiosis in the most ancient group of land plants. Nature Communications 1: 103.

Hunt. G. 1981. Plant Growth Curves: The functional Approach to plant Growth analysis. London, Edward Arnold.

Kottke, I. \& Nebel, M. 2005. The evolution of mycorrhizal-like associations in liverworts: an upadate. New Phytologist 167: 330-334.

Ligrone, R.; Carafa, A.; Lumini, E.; Biancotto, V.; Bonfante, P. \& Duckett, J.G. 2007. Glomeromycotean associations in liverworts: A molecular, cellular, and taxonomic analysis. American Journal of Botany 94: 1756-1777.

Lima, W. L. 2008. Metabolismo do nitrogênio e atividades de bombas de prótons em raízes transgênicas com ácido húmico e simbiose micorrízica arbuscular. Seropédica, 173f. Tese de Doutorado em Ciência do Solo. Instituto de Agronomia, UFRRJ.

Lima, W.L.; Oliveira, J.R.; Saggin Júnior, O.J.; Raposo, T.P.; Alves, G.C.; Silva, E.M.R. \& Berbara, R.L.L. 2006. Editoração de imagens para avaliação do crescimento de plantas ou microrganismos com o programa SIARCS ${ }^{\bullet}$. Seropédica. Embrapa Agrobiologia. 32p. (Boletim de Pesquisa e Desenvolvimento, 14). Disponível em: http://www.cnpab.embrapa.br/ publicacoes/download/bot014.pdf. (Acesso em 10/04/2011)

Moreira, F.M.S \& Siqueira, J.O. 2006. Microbiologia e Bioquímica do Solo. 2.ed. Lavras, Editora UFLA.
Nannipieri, P.; Grego, S.; Dell'Agnola, G.;Nardi, S. 1993. Proprietà biochimiche e fisiologiche della sostanza organica. pp. 67-78. In: Nannipieri, P. (Ed.). Ciclo della sostanza organica nel suolo: aspetti agronomici, chimici, ecologici, ecologici \& selvicolturali. Bologna, Patron.

Nardi, S.; Muscolo, A.; Vaccaro, S.; Baiano, S.; Spaccini, R. \& Piccolo, A. 2007. Relationship between molecular characteristics of soil humic fractions and glycolytic pathway and krebs cycle in maize seedlings. Soil Biology \& Biochemistry 39: 3138-3146.

Neter, J. \& Wasserman, W. 1974. Applied linear statistical models. Homewood, Richard D. Irwin Inc.

Pereira, A.R. \& Machado, E.C. 1987. Análise quantitativa do crescimento de comunidades vegetais. Campinas. Instituto Agronômico n.114.

Read, D.J. 1992. The mycorrhizal mycelium. Pp. 102-133. In: Allen, M.F. (Ed.). Mycorrhizal functioning: An integrative plant-fungal process. New York, Chapman and Hall.

Russell, J. \& Bulman, S. 2005. The liverwort Marchantia foliacea forms a specialized symbiosis with arbuscular mycorrhizal fungi in the genus Glomus. New Phytologist 165(2): 567-579.

Santos, G.A. \& Camargo, F.A.O. 1999. Fundamentos da matéria orgânica: ecossistemas tropicais e subtropicais. Porto Alegre, Gênesis.

Schüßler, A.; Schwarzott, D. \& Walker, C. 2001. A new phylum, the Glomeromycota: phylogeny and evolution. Mycological Research 105: 1413-1421.

Schüßler, A. 2000.Glomus claroideum forms an arbuscular mycorrhiza-like with hornworts Anthoceros punctatus. Mycorrhiza 10: 15-21.

Siqueira, J.O.; Sylvia, D.M.; Gibson, J. \& Hubbell, D.H. 1985. Spores germination and germ tube growth of vesicular-arbuscular mycorrhizal fungi. Canadian Journal of Botany 31: 965-972.

Souza, F.A. \& Declerck, S. 2003. Mycelium development and architecture, and spore production of Scutellospora reticulate in monoxenic culture with Ri T-DNA transformed carrot roots. Mycologia 95(6): 1004-1012.

Souza, F.A.; Stürmer, S.L.; Carrenho, R. \& Trufem, S.F.B. 2010. Classificação e taxonomia e fungos micorrízicos arbusculares e sua diversidade e ocorrência no Brasil. Pp. 15-75. In: Siqueira, J.O.; SOUZA, F.A.; Cardoso, E.J.B.N. \& Tsai, S.M. (Eds.). Micorrizas: 30 anos de pesquisa no Brasil. Lavras, Editora UFLA.

Stevenson, F.J. 1994. Humus chemistry: genesis, composition, reactions. 2nd ed. New York, John Wiley.

Swift, R.S. 1996. Organic matter characterization. Pp. 1011-1020. In Sparks, D.L.; Page, A.L.; Helmke, P.A.; Loeppert, R.H.; Soltanpour, P.N.; Tabatabai, M.A.; Johnston, C.T. \& Sumner, M.E. (Eds.) Methods of soil analysis: chemical methods. Vol. 3. Madison. Soil Science Society of America. American Society of Agronomy, (SSSA. Book Series, 5).

Universidade Federal de Viçosa - UFV. 2000. Sistema de análises estatísticas e genéticas - SAEG. Versão 8.0. Viçosa, MG.

Urchei, M.A.; Rodrigues, J.D. \& Stone, L.F. 2000. Análise de crescimento de duas cultivares de feijoeiro sob irrigação, em plantio direto e preparo convencional. Pesquisa Agropecuária Brasileira 35: 497-506.

Wang, B. \& Qiu, Y.L. 2006. Phylogenetic distribution and evolution of mycorrhizas in land plants. Mycorrhiza 16: 299-363.

Varanini, Z.; Pinton, R.; De Biasi, M.G.; Astolfi, S. \& Maggioni, A. 1993. Low molecular weight humic substances stimulate $\mathrm{H}^{+}$-ATPase activity of plasma membrane vesicles isolated from oat (Avena sativa L.) roots. Plant Soil 153, 61-69.

Zabot, L.; Dutra, L.M.C.; Jauer, A.; Lucca Filho, O.A.; Uhry, D.; Losekan, M.E.; Farias, J.R. \& Ludwig, M.P. 2004. Análise de crescimento da cultivar de feijão BR ipagro 44 guapo brilhante cultivada na safrinha em quatro densidades de semeadura em Santa Maria - RS. Revista de Ciências Agroveterinárias 3(2): 105-115.

Zandonadi, D.B.; Canellas, L.P. \& Façanha, A.R. 2007. Indolacetic and humic acids induce lateral root development through a concerted plasmalemma and tonoplast $\mathrm{H}+$ pumps activation. Planta 225: 1583-1595. 